ISSN 1991-8631

Original Paper

http://indexmedicus.afro.who.int

\title{
Antimicrobial activity of the leaf extracts of Moringa oleifera and Jatropha curcas on pathogenic bacteria
}

\author{
S.I. OKORONDU ${ }^{1^{*}}$, C. O. AKUJOBI ${ }^{1}$, J.N. OKORONDU ${ }^{2}$ and \\ S.O. ANYADO-NWADIKE ${ }^{3}$
}

${ }^{1}$ Department of Microbiology, Federal University of Technology Owerri, P.M.B. 1526, Owerri, Nigeria.

${ }^{2}$ Department of Chemistry, University of Port Harcourt, P.M.B. 5323, Port Harcourt, Nigeria.

${ }^{3}$ Department of Biotechnology, Federal University of Technology Owerri, P.M.B. 1526, Owerri, Nigeria.

${ }^{*}$ Corresponding author, E-mail: sokorondu@yahoo.co.uk

\begin{abstract}
This study evaluates the antimicrobial activity of the leaf extracts of Moringa oleifera and Jatropha curcas against Staphylococcus aureus and Escherichia coli. Different concentrations of the extracts were subjected to these organisms in which Moringa oleifera showed a higher zone of inhibition on Staphylococcus aureus $(2.8 \mathrm{~cm})$ while on E. coli $(2.4 \mathrm{~cm})$ while Jatropha curcas showed a higher zone of inhibition on E. coli $(2.6 \mathrm{~cm})$ while on $S$. aureus $(1.80 \mathrm{~cm})$. The minimum inhibitory concentration (MIC) of Moringa oleifera extract on E. coli and S. aureus were $0.250 \mathrm{mg} / \mathrm{ml}$ and $0.125 \mathrm{mg} / \mathrm{ml}$ respectively while MIC of Jatropha curcas extract on test organisms was $0.125 \mathrm{mg} / \mathrm{ml}$. The quantitative phytochemical screening in $\mathrm{g} / \mathrm{kg}$ revealed the presence of flavonoid 36 and 21, alkaloids 92 and 39, tannins 7.4 and 5.6, saponins 115.0 and 53.5, cyanogenic glycosides 8.4 and 14.5 for M. oleifera and J. curcas respectively. The observed antimicrobial properties could be due to the presence of these bioactive compounds and further substantiates the use of Moringa oleifera and Jatropha curcas leaf extracts in medicine. The extracts in correct doses can successfully be used in vivo to inhibit and eventually kill the test bacteria used in this study.
\end{abstract}

(c) 2013 International Formulae Group. All rights reserved.

Keywords: Moringa oleifera, Jatropha curcas, phytochemicals, bacteria, antimicrobial.

\section{INTRODUCTION}

Plants have been used for centuries before the advent of Orthodox medicine. Leaves, flowers, stems, roots, seeds, fruit and bark can all be constituents of herbal medicines. The medicinal values of these plants depend on their phytochemical components, which produces definite physiological actions on the human body. The most important of these phytochemicals are alkaloids, tannins, flavonoids and phenolic compounds (Afolabi et al., 2007; Okorondu et al, 2010a, b, 2011).

Moringa is the sole genus in the flowering plant family Moringaceae. The genus Moringa in turn is made up of 12 species. Moringa oleifera is the most widely cultivated species of the genus Moringa and it is found in many tropical and sub-tropical regions (Sofowora, 1984). M. oleifera is cultivated and harvested in many areas of the world where other plants are unable to thrive and virtually every part of the moringa tree 
can be used for food, medicine or put some other beneficial use (Farooq et al., 2007). The "moringa" tree is grown mainly in semi-arid, tropical and subtropical areas. It grows best in dry sandy soil, tolerates poor soil, including coasted areas. M. oleifera, commonly referred to as the miracle tree, is the most widely cultivated species of the genus Moringa, which is the only genus in the family Moringaceae. It is a fast growing and resistant shrub, native to India but now widely distributed in the tropics and subtropical areas (Oliver-Bever, 2000). In Nigeria, M. oleifera is encountered doing well in all ecological zones where it is always in season all the year round. The plant is propagated by both seeds and cuttings. The Moringa tree is grown mainly in semi-arid, tropical and subtropical areas. Today, it is widely cultivated in Africa, Central and South America, Sri- Lanka, India, Mexico, Malaysia, Indonesia and the Philippines. It is considered one of the World's most useful trees, as almost every part of the Moringa tree can be used for food or has some other beneficial property (Fahey, 2005).

Jatropha curcas is a plant which belongs to the family Euphorbiaceae originated from Mexico and South Africa (Tint and Mya, 2009). The plant was introduced to Africa by the Portuguese in 1500 and was found growing sparsely in the wild in Nigeria and was use as hedge (Lozan, 2007). J. curcas is a small shrub plant which grows to a height of between $3 \mathrm{~m}$ and $5 \mathrm{~m}$. The bark exudates white coloured latex. The leaves of the plant were arranged alternatively and of large size with green to pale-green colour (Tint and Mya, 2009). J. curcas grows almost anywhere-even on gravelly, sandy and saline soils. It can thrive on the poorest stony soil. It can grow even in the crevices of rocks (Tint and Mya, 2009). The fruits are produced in winter, or there may be several crops during the year if soil moisture is good and temperatures are sufficiently high. The seeds are mature when the capsule changes from green to yellow (Lozan, 2007). J. curcas is a drought - resistant perennial plant, growing well in Marginal / poor soil. It is easy to establish and grows relatively quickly producing seeds for 50 years. J. curcas has limited natural vegetative propagation and is usually propagated by seed. The oil from $J$. curcas seeds is used to treat rashes and parasitic skin diseases. Mixture of oil from the seeds with benzyl benzoate is effective against scabies and dermatitis (Belewu, 2008). The oil can be as a biodiesel as it burns with clear smoke-free flame. The oily seeds are processed into oil, which may be used directly ("Straight Vegetable Oil") to fuel combustion engines or may be subjected to transsterification to produce biodiesel (Belewu, 2008). Jatrophas curcas is commonly called physic nut, purging nut or pig nut. Previous studies have reported that the plant exhibits bioactive activities for fever, mouth infections, jaundice, guinea worm, sores and joint rheumatism (Oliver-Bever, 2000). Aiyelaagbe (2001) reported the anti-parasitic activity of the sap and crushed leaves of $J$. curcas.

The main objective of this project is to determine the antimicrobial activity of the ethanol leaf extracts of Moringa oleifera and Jatropha curcas on selected pathogenic gram positive and gram negative bacteria (Staphylococcus aureus and Escherichia coli).

\section{MATERIALS AND METHODS}

\section{Sample collection and identification}

Healthy leaves of Moringa oleifera and Jatropha curcas were collected from school of Agriculture and Agricultural Technology, Federal University of Technology, Owerri, Nigeria in September; 2011. The taxonomical identification of the plant was confirmed by Dr. S.O. Ojiako, a plant taxonomist of the Department of Crop Science, Federal University of Technology Owerri, Nigeria.

\section{Preparation of plant material}

The fresh leaves of Moringa oleifera and Jatropha curcas were harvested, rinsed with tap water and air-dried under shade for 7 
days. The dried leaves were reduced to fine powder using a mechanical grinder and stored in a sterile container until when needed.

\section{Preparation of the extract}

These were carried out using soxhlet extraction method. $30 \mathrm{~g}$ of the grounded powdered plant material of Moringa oleifera and Jatropha curcas leaves respectively were subjected to sequential extraction using 150 $\mathrm{ml}$ ethanol each for 3 hours. The ethanol extract was concentrated into dryness by evaporation of the solvent in a water bath and the weight was noted. The extract was stored in a sterile container at $4{ }^{\circ} \mathrm{C}$ in a refrigerator until required for use.

\section{Phytochemical analysis}

Phytochemical screening was carried out on the powdered sample for the presence of bioactive compounds such as alkaloids, flavonoids, tannins, saponins and cyanogenic glycosides using standard procedures as described by Harborne (1973) and AOAC (1984).

\section{Test for alkaloid}

A measured weight $(2 \mathrm{~g})$ of each processed sample was dispersed in $100 \mathrm{ml}$ of $10 \%$ acetic acid in ethanol solution to stand for 4 hours at room temperature with shaking every 30 mins. At the end of this period, the mixture was filtered through Whatman filter paper. The filtered extract was treated with addition of concentrated ammonia solution in drops to precipitate the alkaloids. The precipitated alkaloid was filtered using Whatman filter paper. After washing with $1 \%$ $\mathrm{NH}_{4} \mathrm{OH}$ solution, the precipitated alkaloid was dried at $6{ }^{\circ} \mathrm{C}$ and weighed after cooling in a desiccator.

\section{Test for flavonoid}

A measured weight $(5 \mathrm{~g})$ of the processed samples was boiled in $100 \mathrm{ml}$ of 2 $\mathrm{M} \mathrm{HCl}$ solution for 40 minutes. It was allowed to cool to room temperature before being filtered through Whatman filter paper to obtain the extract. Flavonoid in the extract was then precipitated by addition of concentrated ethyl acetate in drops until in excess. The flavonoid precipitate was recovered in weighed filter paper following filtration. After drying in the oven and cooling in a desiccator, the weight of flavonoid was obtained.

\section{Test for saponins}

$5.0 \mathrm{~g}$ of dry ground samples was weighed into a thimble and transferred into a soxhlet extractor chamber fitted with a condenser and a round bottom flask. 10\% acetic acid is poured into the flask. The sample was exhaustively extracted of its lipid and interfering pigments for 3hours by heating the flask on a hot plate and the solvent distilled off. A pre-weighed round bottom flask was fitted into the soxhlet apparatus (bearing the sample containing thimble) and ethanol poured into the flask. The saponin is then exhaustively extracted for 3 hours by heating the flask on a hot plate after which the solvent is distilled off. The flask is reweighed. The difference between the final and initial weights of the flask represents the weight of saponin extracted.

\section{Test for cyanogenic glycoside}

$1.0 \mathrm{~g}$ dry ground sample was weighed into a $250 \mathrm{ml}$ round bottom flask. $200 \mathrm{ml}$ of distilled water was added and allowed to stand for 2 hours. An antifoaming agent (silicon oil) was added before distillation. Full distillation was then carried out and 150-170 $\mathrm{ml}$ of distillate was collected in a $250 \mathrm{ml}$ conical flask containing $20 \mathrm{ml}$ of $2.5 \% \mathrm{NaOH}$. To 100 $\mathrm{ml}$ of the distillate containing cyanogenic glycoside, $8 \mathrm{ml}$ of $6 \mathrm{~N} \mathrm{NH}_{4} \mathrm{OH}$ and $2 \mathrm{ml}$ of $5 \%$ $\mathrm{KI}$ was added, mixed and titrated with $0.02 \mathrm{~N}$ silver nitrate $\left(\mathrm{AgNO}_{3}\right)$ using a micro burette.

\section{Test for tannin}

Measured weight of the samples (5.0 g) was dispersed in $100 \mathrm{ml}$ of distilled water. The mixture was shaken for 30 minutess at room temperature and filtered using Whatman 
filter paper. The residue was washed further with the distilled water until $100 \mathrm{ml}$ filtrate was obtained. An aliquot of the extract $(2 \mathrm{ml})$ was mixed with equal volume of folin-Dennis reagent in a $50 \mathrm{ml}$ volumetric flask. $2 \mathrm{ml}$ of saturated sodium carbonate solution was added. The mixture was diluted to the $50 \mathrm{ml}$ mark and allowed to incubate for 90 minutes at room temperature. A standard tannin solution was prepared with tannic acid. After incubation, the absorbance of the standard and samples were measured at $760 \mathrm{~nm}$ in a spectrophotometer.

Isolation and identification of test
organisms

Two pathogenic bacterial isolates of Escherichia coli and Staphylococcus aureus obtained from the Microbiology department of Federal Medical Centre, Owerri, Nigeria were used for the study. They were isolated and purified on nutrient agar plates, characterized and identified (Cheesbrough, 2002).

\section{Antimicrobial screening}

Two approaches were used for the evaluation of the antimicrobial activities of the plant extracts as described by Okigbo et al. (2003).

\section{Antimicrobial susceptibility test/ Zone of inhibition}

Antimicrobial activity of the extracts was determined by Agar- well diffusion method using the test organisms; E. coli and $S$. aureus. An agar media was prepared and a sterile cork borer of about $6 \mathrm{~mm}$ in diameter was used to bore holes on the agar media. The already characterized test organisms were swabbed on the solid agar media. Aliquots of $0.2 \mathrm{ml}$ of the extract was introduced in the holes made on the agar media containing each isolate of organisms, at different concentrations of $(1,0.5,0.25,0.125,0.0625$ $\mathrm{mg} / \mathrm{ml}$ ) of the two (2) extracts (M. oleifera and J. curcas). A control hole where the solvent used for the extraction was added and the plates were incubated at $37^{\circ} \mathrm{C}$ for $24 \mathrm{hrs}$ in the incubator. The ability of the various extracts to inhibit growth of the clinically significant bacteria was measured and recorded as diameter of the zone of inhibition in $\mathrm{cm}$.

\section{Determination of Minimum Inhibitory Concentration (MIC)}

The minimum inhibitory concentration (MIC) of the extracts was determined by incorporating constant volumes $(0.2 \mathrm{ml})$ of each dilution of the extract into the punchholes made on the agar medium. Aliquot of the extract $0.2 \mathrm{~g}$ was dissolved in $100 \mathrm{ml}$ of sterile distilled water to obtain $2.0 \mathrm{mg} / \mathrm{ml}$. This $2.0 \mathrm{mg} / \mathrm{ml}$ concentration was then doubly diluted in sterile distilled water to obtain concentrations of $1,0.5,0.25,0.125,0.0625$ $\mathrm{mg} / \mathrm{ml}$. The minimum inhibition concentration was determined by recording the least concentration of the extracts $(\mathrm{mg} / \mathrm{ml})$ or the highest dilution that inhibited the growth of the organisms.

\section{RESULTS}

The percentage yield of the ethanol leaves extract of $M$. oleifera and J. curcas were shown in Table 1. Crude extract (3.19 g) of Moringa oleifera and $3.04 \mathrm{~g}$ of Jatropha curcas were extracted from $30 \mathrm{~g}$ powder of samples. These were converted in percentage to give $10.63 \%$ and $10.13 \%$ respectively. Table 2 shows the quantitative analysis of bioactive compounds of ethanol leaf extract of M. oleifera and J. curcas. The phytochemicals present in $\mathrm{g} / \mathrm{kg}$ are flavonoid 36 and 21 , alkaloids 92 and 39, tannins 7.4 and 5.6, saponins 115 and 53.5, cyanogenic glycosides 8.4 and 14.5. These values are for M. oleifera and $J$. curcas respectively. Table 3 shows the antimicrobial activities of leaf extracts of $M$. oleifera and $J$. curcas on the test organisms (Escherichia coli and Staphylococcus aureus). At concentrations of $1.00 \mathrm{mg} / \mathrm{ml}, 0.50 \mathrm{mg} / \mathrm{ml}$, $0.25 \mathrm{mg} / \mathrm{ml}, 0.125 \mathrm{mg} / \mathrm{ml}$ and $0.0625 \mathrm{mg} / \mathrm{ml}$, M. oleifera extract inhibited $E$. coli by 2.40 $\mathrm{cm}, 2.00 \mathrm{~cm}, 1.60 \mathrm{~cm}, 0.00 \mathrm{~cm}$ and $0.00 \mathrm{~cm}$ respectively while $J$. curcas extract inhibited 
E. coli by $2.60 \mathrm{~cm}, 2.20 \mathrm{~cm}, 1.40 \mathrm{~cm}, 1.00 \mathrm{~cm}$ and $0.00 \mathrm{~cm}$ respectively. In the same manner $M$. oleifera extract inhibited $S$. aureus at the same concentrations by $2.80 \mathrm{~cm}, 2.20 \mathrm{~cm}$, $1.80 \mathrm{~cm}, 1.00 \mathrm{~cm}$ and $0.00 \mathrm{~cm}$ respectively while $J$. curcas extract inhibited $S$. aureus by $1.80 \mathrm{~cm}, 1.40 \mathrm{~cm}, 1.20 \mathrm{~cm}, 0.80 \mathrm{~cm}$ and 0.00 $\mathrm{cm}$ respectively. Table 4 shows the minimum inhibitory concentrations (MIC) of leaf extracts of M. oleifera and J. curcas on E. coli to be $0.1250 \mathrm{mg} / \mathrm{ml}$ and $0.125 \mathrm{mg} / \mathrm{ml}$ respectively while on $S$. aureus the MIC results are $0.125 \mathrm{mg} / \mathrm{m}$ and $0.125 \mathrm{mg} / \mathrm{ml}$ respectively.

Table 1: Ethanol extraction yield of Moringa oleifera and Jatropha curcas leaves.

\begin{tabular}{lcc}
\hline Leave extract & Weight of crude extract $(\mathbf{g})$ & Percentage yield $(\boldsymbol{\%})$ \\
\hline Moringa oleifera & 3.19 & 10.63 \\
Jatropha curcas & 3.04 & 10.13 \\
\hline
\end{tabular}

Table 2: Quantitative estimation (\%) of bioactive compounds of ethanolic leaves extract of $M$. oleifera and J. curcas.

\begin{tabular}{lcc}
\hline Secondary metabolites & \multicolumn{2}{c}{ Concentration of phytochemicals present $(\mathbf{g} / \mathbf{k g})$} \\
\cline { 2 - 3 } & M. oleifera & J. curcas \\
\hline Flavonoids & 36.0 & 21.0 \\
Alkaloids & 92.0 & 39.0 \\
Tannins & 7.4 & 5.6 \\
Saponins & 115.0 & 53.5 \\
Cyanogenic glycosides & 8.4 & 14.5 \\
\hline
\end{tabular}

Table 3: Antimicrobial activity of the leaf extracts of Moringa oleifera and Jatropha curcas on the test organisms at different concentrations.

\begin{tabular}{|c|c|c|c|}
\hline \multirow[t]{2}{*}{ Plant extract } & \multirow{2}{*}{$\begin{array}{c}\text { Conc. of crude extract } \\
(\mathrm{mg} / \mathrm{ml})\end{array}$} & \multicolumn{2}{|c|}{ Diameter zones of inhibition (cm) } \\
\hline & & E.coli & S. aureus \\
\hline \multirow{5}{*}{ M. Oleifera } & 1 & 2.4 & 2.8 \\
\hline & 0.5 & 2.0 & 2.2 \\
\hline & 0.25 & 1.6 & 1.8 \\
\hline & 0.125 & - & 1.0 \\
\hline & 0.0625 & - & - \\
\hline \multirow{5}{*}{ J. curcas } & 1 & 2.6 & 1.8 \\
\hline & 0.5 & 2.2 & 1.4 \\
\hline & 0.25 & 1.4 & 1.2 \\
\hline & 0.125 & 1.0 & 0.8 \\
\hline & 0.0625 & - & - \\
\hline
\end{tabular}


Table 4: The minimum inhibition concentration of leaf extracts of Moringa oleifera and Jatropha curcas $(\mathrm{mg} / \mathrm{ml})$.

\begin{tabular}{lcc}
\hline Test Organism & M. oleifera & J. curcas \\
\hline Escherichia coli & 0.250 & 0.125 \\
Staphylococcus aureus & 0.125 & 0.125 \\
\hline
\end{tabular}

\section{DISCUSSION}

The result of this investigation revealed that the leaf extracts of Moringa oleifera and Jaropha curcas possesses appreciable antimicrobial activity against Staphylococcus aureus and Escherichia coli. The extracts inhibited the growth of Escherichia coli and Staphylococcus aureus at various concentrations. The minimum inhibition concentration of the both leaf extracts on the test organisms ranged between $0.250 \mathrm{mg} / \mathrm{ml}$ and $0.125 \mathrm{mg} / \mathrm{ml}$. Quantitative phytochemical screening in percentage of the dried leaf extracts of M. oleifera and J. curcas revealed the presence of some phytochemical constituents (flavonoids, alkaloids, tannin and saponins). Rehilla et al. (1994) observed that there is need for local herbs to be evaluated for phytochemistry to determine the potential of indigenous source of medicine. Studies elsewhere (Bukill, 1995; Sofowora, 1996 and Timwesizy, 1996) associated medicinal property of plants extract to the presence of alkaloid and essential oil. Harborne (1973) found flavonoid to have antimicrobial effect against wide range of microorganisms in vitro, also Lipophilic flavonoids were found to disrupt microbial membranes (Tsuchiya et al., 1994). Pure isolated plant alkaloids and their synthetic derivatives are used as basic medicinal agent for their analgesic and antibacterial effects (Stray, 1998). Phytochemicals with bitter taste such as alkaloids and flavonoids has been found in this study to possess antimicrobial properties. Anthropologists theorize that animals evolved a tendency to seek out bitter plant parts in response to illness (Huffmann, 2003). Hutching et al. (2003) reported that sick animal tend to forage plant rich in secondary metabolites such as tannin and alkaloids. Flavonoids have been reported to have in vitro antimicrobial activity against a wide range of microorganism because lipophilic flavonoids disrupt microbial membranes (Tsuchiya et al., 1994). Plants are useful as drugs because of the chemically active ingredients that they contain (Singh, 2004). Janovska et al. (2003) reported that antimicrobials of plant origin are not usually associated with any side effects and have enormous therapeutic potentials to heal many infectious diseases. The results obtained showed that these secondary metabolites in the plant extracts are responsible for the inhibition of the test bacteria. These plant secondary metabolites exhibit various biochemical and pharmacological actions in animals and microorganisms when ingested (Calixto, 2000), and have potentially significant application against human pathogens (ElMahmood et al., 2008). Several authors have linked the presence of these bioactive compounds to the antimicrobial properties of crude plant extracts (Afolabi et al., 2007). Moringa oleifera and Jatropha curcas contain $8.4 \mathrm{ppm}$ and $14.5 \mathrm{ppm}$ respectively of hydrogen cyanide. FAO/WHO, (1991) recommended $10 \mathrm{ppm}$ as safe level for cyanide toxicity. Cardoso et al. (2005) reported 40ppm to 46ppm after heap fermentation of cassava and Okorondu et al. (2008) reported 18.85ppm hydrogen cyanide in Mucuna pruriens (velvet bean) after 4 days fermentation and $1 \mathrm{hr}$ boiling. The cyanide level in the extracts of Moringa oleifera and Jatropha curcas are within safe level.

The effects of the different concentrations of both plant extracts on the bacterial isolates with respect to the zone of 
inhibition gave a good linearization response for both organisms. In general, the extracts showed a concentration dependent inhibition effect on the bacterial isolates. This finding correlates with the reports of Ekpendu et al. (1994), Ogbeche et al. (1997) and Aiyelagbe et al. (2001), who independently found that various plants inhibited the growth of some clinical bacterial isolates.

\section{Conclusion}

In conclusion, the leaf extract of Moringa oleifera and Jatropha curcas have antimicrobial activity against Escherichia coli and Staphylococcus aureus. This inhibitory action of the extracts could be attributed to the presence of the phytochemical constituents in the plant extracts such as alkaloid, flavonoid, and saponin. The extracts in correct doses can successfully be used in vivo to inhibit and eventually kill the test bacteria used in this study. Some antibiotics have become almost obsolete because of the problem of drug resistance caused by microbial mutation over the years, the consequence of drug resistance implies that new drugs both synthetic and natural must be sought to treat disease for which known drugs are no longer effective. Further research probably involving in vivo assay would be needed to establish the relationship between the MIC's obtained in this study and the effective doses at which the herbs can be applied in traditional practice. Investigation can combine the different plant extract for possible synergistic effect. These plant extracts should be tested on other human pathogens to ascertain their spectrum of effectiveness. Following rampant grazing by animals especially cow flocks and indiscrimination bush burning followed by urbanization and deforestation, there is need to have medicinal plant garden where medicinal plants can be properly kept and maintained. The production can be expanded and extensive research carried out on them.

\section{REFERENCES}

Afolabi C, Akinmoladun EO, Ibukun I, Emmanuel A, Obuotor EM, Farombi EO. 2007. Phytochemical constituent and antioxidant activity of extract from the leaves of Moringa oleifera. Scientific Research and Essay, 2(5): 163-166.

AOAC (Association of Official Analytical Chemists). 2007. Official methods of analysis $\left(14^{\text {th }} \mathrm{edn}\right)$. AOAC: Washinton D. C.

Belewu O. 2008. Natural Plant chemicals sources of industry and mechanical materials. Science, 27: 1154-1162.

Bukill HM. 1995. The Useful Plants of West Tropical Africa ( $2^{\text {nd }}$ edn, vol. 3). Families E.I. Royal Betanical Gardens: Kew; 636p.

Cardoso AP, Mirione E, Ernesto M, Massaza F, Cliff J, Haque MR, Bradbury JH. 2005. Processing of cassava roots to remove cyanogens. J. Food Composition Analysis, 18: 451-460.

Calixto JB. 2000. Efficacy; safety and quality control, marketing regulatory guidelines for herbals (Phytotherapeutic agents). Brazilian Journal of Medical Biological Research, 33: 179-189.

Cheesbrough M. 2002. District Laboratory Practices in Tropical Countries ( $\left.2^{\text {nd }} \mathrm{edn}\right)$. Cambridge, London; 100-181.

Ekpendu TO, Akahomeju AA, Okogun JI. 1994. Anti-inflamatory and antimicrobial activities of Mitrocarpusscaber extracts. International Journal of Pharmacology, 32(2): 191-196.

El-Manhood AM, Doughari JH, Ladan N. 2008. Antimicrobial Screening of Stem bark extracts of Vitellaria paradoxa against some enteric pathogenic microogganism. African Journal of Pharmacy and Pharmacology, 2(5): 8994.

Fahey ON. 2005. Antibacterial activities of crude extract of Sennaalata. Bioscience Research Communications, 10(3): 181184.

FAO/WHO. 1991. Joint FAO/WHO Food Standard Programme. Codex 
Alimentarius Commission XII, Supplement 4, FAO, Rome, Italy.

Harborne JB. 1973. Phytochemical Methods: A Guide to Modern Techniques of Plant Analysis. Chapman and Hall Ltd: London; 279p.

Huffmann MA. 2003. Animal self-medication and ethomedicine: exploration of the medicinal properties of plants. Proc. Nutr. Soc., 62(2): 371-381.

Hutchings MR, Athanasiadous S, Kynazakis I. and Gordon IJ. 2003. Can animals use foraging behaviour to combat parasites? Proc. Nutr. Soc., 62(2): 301.

Janovska D, Kubikova K, Kokoska L. 2003. Screening for Antimicrobial activity of some medicinal plant species of traditional Chinese medicine. Czech $J$. Food Sci., 21: 107-110.

Lozan DE. 2007. Evaluation of diacetyl antimicrobial activity against E. coli: L. monocytogens and S. aureus. Food Microbiology, 20: 557-543.

OgbecheAK, Ajayi GO. andOnyeneta P. 1997. Antimicrobial activities of the leaf extract of Ageratum conizodes. Nigerian Journal of Medicine, 7: 397-399.

Okigbo RN, Emeogene AO. 2003. Effect of leaf extracts of three plant species on Mycospherellafijiensis, the causal organism of black sigatoka disease of banana (Musa acuminate). Nigerian Journal of Plant Protection, 19: 10-15.

Okorondu SI, Aririatu LE, Okorondu MMO. 2008. The effects of Fermentation and Boiling on the level of hydrogen cyanide in Mucuna pruriens (velvet bean).International J. Tropical Agriculture, 2: 268-271.

Okorondu SI, Aririatu LE, Chinakwe EC, Braide W. (2010a). Antibacterial Properties of Picralima nitida Seed Extract. Current Trend in Microbiology, 6: 13-19.
Okorondu SI, Mepba HD, Okorondu MMO, Aririatu LE. 2010b. Antibacterial Properties of Musa paradisiaca Peel Extract. Current Trend in Microbiology, 6: 21-26.

Okorondu SI. 2011. Evaluation of the Antifungal Properties of Picralima nitida Seed Extracts. International Journal of Natural and Applied Sciences, 7(1): 4146.

Oliver-Bever DC. 2000. Medicinal Plants in Tropical West Africa. Cambridge University Press: London.

Rehilla T, Rukhasandra N, Zaichi AA, Shamshila R. 1994. Phytochemical Screening of medicinal plants belonging to family Eupheribiaceae. Pak Vert J., 14: $100-112$.

Singh BD. 2004. Biotechnology (5 $5^{\text {th }}$ edn). Kalyani publishers: New Delhi, Calcutta, India.

Sofowora PK. 1984. Antimicrobial and Chemo-preventive properties of herbs and spices. Current Medical Chemistry, 19511960.

Sofowora AE. 1996. Research on medicinal plants and traditional medicine in Africa. J. Alt. Compl. Med., 2(3): 365-372.

Stray F. 1998. The Natural Guide to Medicinal Herbs, and Plants. Tiger Books International: London; 12-16.

Tsuchiya H, Sato M, Linuma M, Yokoyama J, Ohyama M, Tanaka T, Takase I, Namikawa I. 1994. Inhibition of the growth of carcinogenic bacteria in vitro by the plant flavonones. Experimentia, 50: $846-849$.

Timwesizy O. 1996. Bumetha Rukarere: Integrating modern and traditional health care in south west Uganda. J. Alt. Compl. Med., 3(3): 373-376. 